\title{
CROWN COPYRIGHT REGULATION IN THE UK - IS THE DEBATE STILL ALIVE?
}

\author{
Dr. STEPHEN SAXBY ${ }^{1}$
}

\section{ABSTRACT}

Having been an observer of public policy towards Crown copyright for a number of years now it is interesting to see just how far government has moved over the past decade in its stance on the issue. What began as a fairly entrenched viewpoint that Crown copyright was a necessary instrument of control of the process of official publication, seems now to have moved forward to a position that permits more radical thinking about the policy. Originally the enforcement of Crown copyright was seen as a means of maintaining control over the publication of the material, with a licencing policy for re-use and added-value exploitation by the private sector publishing industry. The private sector itself had long argued that the policy diminished prospects for the proper exploitation of official information. This it argued had had a detrimental effect, both for the industry itself and the levels to which the information might be used for the benefit of the national economy. Government began to listen to these arguments but HM Treasury consistently maintained the need for departments and agencies to recover costs and in some cases obtain profits from the distribution of official information. It was seen very much as a resource belonging to cost centres that should be exploited. Since the fall of the former Conservative Government it has become clear that those engaged in this debate are no longer as committed to these trenchant positions as they once were. Instead it would seem that a more open debate is underway within a broader reassessment of the nature, organization and functioning of the public services. This article explores the progress in that debate and assesses where the policy now stands.

\section{What is Crown copyright?}

Crown copyright is defined by s. 163 of the Copyright Designs and Patents Act 1988 as covering those works "...made by Her majesty or by an officer or servant of the Crown in the course of his duties". This definition includes databases made in this way as well as works commissioned by government departments from the private sector. The understanding that a work no longer qualifies for Crown copyright protection simply because it was made "under the direction or control" of the Crown or first published by it has resulted in the creation of a separate and distinct Parliamentary copyright to encompass works produced in such manner by either House of Parliament. ${ }^{2}$

It is clear that the origins of its creation can be traced to several acts of piracy of official information in the 1880's and the desire of government thereafter to control such publication itself. The need to ensure the integrity of such publications was identified as well as a desire to "protect the general taxpayer against the commercial interests of the few who would obtain a private profit by unrestricted freedom to reproduce official matter". ${ }^{3}$ It would seem that these two policy

\footnotetext{
${ }^{1}$ Reader in Information Technology Law, University of Southampton

${ }^{2}$ See: Crown Copyright in the Information Age, Cm 3819 (SO January 1998) para. 2.8.

${ }^{3}$ Ibid., para. 2.3. 
objectives were the driving force for development of Crown copyright regulation as it entered the $20^{\text {th }}$ Century. In 1889 Letters Patent were granted to the Controller of Her Majesty's Stationery Office (HMSO) to administer and control the exercise of Crown copyright. Departmental wishes in relation to Crown copyright were always taken into account and, prior to the Second World War, this was reflected in the policy of the Copyright Unit of HMSO, to grant departments limited powers to licence Crown copyright material within general guidance laid down by the Controller. HMSO continued under these terms of reference until May 2005 when it became part of the new Office of Public Sector Information (OPSI). HMSO continues to function but within an Office whose key task will be to co-ordinate policy standards within government on the re-use of public sector information.

\section{The policy review}

\subsection{The 1998 Green Paper}

The whole history of Crown copyright regulation is well documented in the consultation document and Green Paper, Crown Copyright in the Information Age ${ }^{4}$, published in January 1998. One can see for the first time in this document how consideration of reform of Crown copyright, first initiated by the Conservatives, now sat within the broader agenda of modernisation of the public sector. Themes such as freedom of information, the growth of the electronic information industry and the prospects for electronic service delivery by government to citizens all featured in the paper. Its purpose was to seek views from the public on a range of options "for the future management of Crown copyright".

There is no doubt that the timing of this policy review, both in respect of Crown copyright and government service delivery generally, was influenced by the arrival of the Internet in the 1990's and the political realisation that this had the potential for radical new forms of communication delivery and engagement with the voter and other information users. The traditional rationale for Crown copyright regulation, already described, found itself under pressure. Relaxations were introduced through the licensing regime and through the series of explanatory statements produced under the terms of "Dear Publisher" and "Dear Librarian" letters. However, the policy was under pressure. To begin with, on 1 October 1996, the trading arm of HMSO was privatised becoming "The Stationery Office" (TSO). HMSO remained in existence, however, as the regulator of Crown copyright, the Copyright Unit being transferred into that residuary body. The result of this was an expectation that, given regulation was now a commercial decision for departments, a larger volume of first publication rights ${ }^{5}$ might now be granted to private sector publishers in competition with TSO. ${ }^{6}$ This would be both for works with significant sales potential or those with less appeal where there was, nevertheless, an obligation upon the department concerned to publish. Different contractual arrangements would apply in each case so that, in the latter instance, a publisher might seek some sort of subsidy from the department to offset the cost of publication. A publisher might also seek certain guarantees about facsimile versions of the work that might be produced by other publishers at a fraction of the origination cost. The idea that the Government maintained an "official publisher" under its direct control had now gone, the consequence being that the process was now entirely a commercial one, mainly for departments and Trading Fund operators to run, with residual regulation of Crown copyright maintained through HMSO.

\footnotetext{
${ }^{4}$ Op.cit., note 2 ante.

${ }^{5}$ This refers to the publication, in any format, of Crown copyright material which has not previously been published.

${ }^{6}$ This assumes of course that the department concerned does not set up its own publishing arm, e.g. Health and Safety Executive which has its own commercial publishing operations.
} 
It was clear at this stage that the policy had a number of loose ends. To begin with commercial publishers would always find themselves in licence negotiation for each new project with which they were contemplating an involvement. This was time consuming and specific to the needs and approach taken by the relevant department or trading fund. Publishers were frequently interested in developing "value-added" products and services based on official information; particularly that which might otherwise lie dormant because it was not core to departmental responsibilities. Departments and agencies approached such requests on the basis of the traditional policy that tax payers' interests must be protected. HM Treasury pressure was also prevalent. This required departments to exploit their information assets in such a way as to recover operating costs from commercial activity. In addition there was some uncertainty, no doubt felt by both sides, that the vast store of official information was not being fully exploited. This encompassed so-called "grey literature" - information collected by departments that might have value, but was not necessarily published. In the Government's view it was possible that such information "could be successfully developed by the information industry and others," but it was not always easy to identify it. ${ }^{7}$

The Green Paper went on to assess whether there was a need for retention of Crown copyright and the options that might be considered. These included a variety of retention or waiver proposals in respect of defined categories of material, complete or partial abolition of Crown copyright, or the creation of a "departmental copyright" -effectively devolving responsibility for the exercise of the policy to the latter. A final alternative canvassed the idea of centralising the administration of Crown copyright within a common set of standards, applying to all departments and operated as a 'one stop shop'.

An Annex to the Green Paper ${ }^{8}$ gave details of the actual sums received from Crown copyright in 1996-97 from departments and agencies. This was the first time such figures had been published by government. The total amount received was just short of $£ 200$ million. Of this sum, $£ 4.3$ million was derived from payments made by commercial publishers in the form of a sales-based royalty for publications undertaken on behalf of a Department or Agency. $£ 40.9$ million came from cases where Departments or Agencies sold data, usually in electronic format, to "value-added" publishers or information providers, ${ }^{9}$ whereas $£ 25.8$ million was paid by publishers, organisations or individuals for licensing permission to reproduce Crown copyright material. ${ }^{10}$ The remaining $£ 128.2$ million came from direct sales income where the Department or Agency published the material itself.

It is interesting to break these figures down a little further. $63 \%$ of the sales-based royalty income derived from just two sources: the Department of Environment, Transport and The Regions and the Office for National Statistics. 95\% of income from data sold to "value added" publishers was generated by four units: the Meteorological Office, HM Land Registry, Ordnance Survey and the Department of Trade and Industry, whereas $87 \%$ of all licensing income came from Ordnance Survey alone. Finally, with direct sales income accounting for more than $64 \%$ of all revenues from Crown copyright, $87 \%$ of this total was generated from just five sources: the Evaluation and Research Agency (of the Ministry of Defence), the UK Hydrographic Office, the Meteorological Office, the Health and Safety Executive and Ordnance Survey. ${ }^{11}$ In fact, together with the Land Registry and the Department of Trade and Industry, these seven entities accounted for nearly 90\%

\footnotetext{
${ }^{7}$ Op Cit., note 2 ante, para 3.9.

${ }^{8}$ Annex B, p. 35

${ }^{9}$ In some cases the data may already have been published by the Department or Agency concerned.

10 This would be granted by Departments and Agencies under delegated authority from the Controller of HMSO.

${ }^{11}$ It is also true that of the seven Departments and Agencies mentioned, more than one third of the entire revenue from Crown Copyright (£69 million) was produced by Ordnance Survey alone.
} 
of all revenues generated by Crown copyright policies. The trend continued in 1998-99 with trading fund operators ${ }^{12}$ accounting for $92 \%$ of the $£ 340$ million publishing and licensing income of the Government in that year. ${ }^{13}$

Given that this data was provided within the Green Paper, it is a little surprising that this did not lead to a discussion about the implications of the figures. What was the Government's reaction, for example, to the limited group of revenue earners dominating the Crown copyright marketplace? Was this an indication of passivity so far as the rest of Whitehall was concerned? Were opportunities being lost to bring public sector information to the attention of the public and particularly to business whose needs for accurate and timely access to a range of official information were obvious? What the Green Paper did do though was to examine the broader arguments for retention or abolition of Crown copyright and, by doing so, begin to open up the debate and direct attention to some of the key policy issues.

It was clear from this discussion that the need for departments and agencies to contribute revenue where they could was an argument for retention of Crown copyright: "If ... departments were unable to generate income from the material which they originate, they would be faced either with restricting the scale of their operations or seeking extra funding from the Exchequer, thus placing an additional burden on the taxpayer”.

In addition, the Green Paper suggested that, without some form of copyright protection in place, private sector publishers might be "put off" investing in the publication of official works of government since this might be undermined by competition. On the other hand, removal of all restrictions on Crown copyright might "lead to the growth of the information market and assist the Government's aims for the UK to be a leader in the Information Age". The private sector would be able to "exploit actively the wealth of unpublished information" that the Government held. There was also the rider that, given the development of the Internet, the policing and enforcement of Crown copyright in such a domain might prove impractical anyway.

\subsection{The Government's response - the 1999 White Paper}

The opening sentence of the 1999 White Paper read: "Our review of Crown copyright has been produced against a backdrop of radical changes in the ways Government delivers services to the citizen and the opportunities presented by information technology as a tool in communicating that information". ${ }^{14}$ This can be taken as a significant comment as it appears to mark a change in the context within which the policy on the future of Crown copyright was being reviewed by government. Up to this point there was a clear sense that the issue was an isolated one in which the key question was how effective Crown copyright regulation could become in terms of its established aims of protecting official information from "inappropriate exploitation", and facilitating public access, where possible, while seeking satisfactory financial returns for commercial exploitation where this took place.

The change that had taken place was heralded by another Government publication of the same month in which the Prime Minister and the Minister for the Cabinet Office presented Parliament

\footnotetext{
${ }^{12}$ A Trading Fund is regulated by the Government Trading Act 1990 (c.30). It represents a financing mechanism for government trading activities by establishing an autonomous operation with its own capital base. In April 2004 there were 21 trading funds in operation.

${ }^{13}$ Cost Cutting Review of the Knowledge Economy, (HM Treasury July 2000) para 1.5.

${ }^{14}$ The Future Management of Crown Copyright, Cm 4300 (SO March 1999) para. 1.1.
} 
with its strategic plans for the modernisation of government itself. ${ }^{15}$ This paper sought to present a strategic framework and a set of principles that would, from now on, guide the Government's approach to the delivery of public services. Three aims were identified: "ensuring that policy making is more joined up and strategic; making sure that public service users, not providers, are the focus by matching services more closely to people's lives; and delivering public services that are high quality and efficient". ${ }^{16}$ From now on there would be a "new drive to remove unnecessary regulation". The principles governing consultation on Crown copyright reform had taken on the broader objectives of "opening up access and encouraging public participation in government". ${ }^{17}$ This might be facilitated by "requiring official information to be readily available to all"18 supported by new technology to improve that access and help the citizen fulfil that role.

Having articulated its new philosophy, the Government began by indicating that consideration of all the responses to the Green Paper had not deflected it from its view that the appropriate course for the future development of Crown copyright was that of "evolution not revolution". It drew attention to the increasing volume of official information then available on its $<w w w$.open.gov.uk $>$ website ${ }^{19}$ and to the growth in public access to the Internet. Future Crown copyright regulation should cater, not only for business, commercial and specialist interest groups, but also for the public at large.

The first issue to arise was the role of HMSO and the Queen's Printer. Respondents had criticised the licensing arrangements in which authority devolved to individual departments. This had led to a lack of consistency and transparency in such matters. In commenting on this the Government recognised the importance of finding the right level of operational autonomy for originating departments, while retaining overall control of the policy within the authority of the Controller of HMSO as independent regulator. Accordingly, formal devolution of licensing powers would continue, but a duty would rest on the shoulders of originating departments to formulate and publish clear licensing terms and charging structures. Other changes would include guidance to departments, stating that the latter should not grant exclusive rights, assignments or transfers of Crown copyright protected material without specific authorisation from the Controller or operate "embargo arrangements" that might, through licensing schemes, deny access to material officially released or published by the Crown. Moreover, departments should not "erect or create any obstacles which prevent the private sector or others from obtaining licences to reproduce Crown copyright protected material or using such material”. ${ }^{20}$ Instead, departments would be encouraged to act proactively in encouraging access to their data and promote its quality, especially by electronic provision and to act without delay in making material available, whether by licence or otherwise. The Controller of HMSO would work with departments to ensure that licensing practice was "consistent with the general principles under the new regime". ${ }^{21}$

The second issue to receive comment in the White Paper concerned licensing practice and its administration. There was recognition among respondents as to the need to preserve "the integrity and official status" of government material. This gave it a kind of "kite mark" effect of quality identifying its status and authority. This should not be lost. Beyond that there were occasions when government had to act to protect official information from exploitation, where UK security interests

\footnotetext{
${ }^{15}$ Modernising Government, Cm 4310 (SO March, 1999).

${ }^{16}$ Ibid., Executive Summary.

${ }^{17}$ Op. cit. note 14 ante, para. 2.1

${ }^{18}$ Ibid.

${ }^{19}$ Now ,www.direct.gov.uk..

${ }^{20}$ Ibid, para. 4.3 .

${ }^{21}$ Ibid.
} 
or some forms of personal data ${ }^{22}$ were involved, or where a risk of fraud arose. ${ }^{23}$ On the main question of licensing policy, respondents wanted to see further relaxations in the form of waivers, fast track or blanket licenses and "light touch management" for material where it lay in the Government's best interests to encourage unrestricted use. The Government took this opportunity to list a range of Crown material where "formal and specific licensing" would not be necessary, provided the copyright "safeguard" was in place in the information itself. ${ }^{24}$ It also declared its intent to feature licensing terms centrally on HMSO's website and on departmental sites.

Important comments were reserved in the White Paper for the commercial exploitation of Crown copyright material. Where commercial "re-publication" of material was proposed, publishers would be directed to a streamlined "single point of access" via HMSO's website for charging structures, with links back to departmental sites. This would address the criticism that such information was "difficult to locate". ${ }^{25}$ However, the so-called "value-added" component ${ }^{26}$ - which required republishers to "add value to original Crown copyright material" as a pre-condition to the grant of licensing permission - was criticised by respondents but retained. In the Government's words, it was necessary to retain this component so as to "protect the public from confusion over the availability of works which purport to be replica works and which have the potential to mislead". ${ }^{27}$

A more complex regulatory issue arose where official material was published on behalf of government by private sector publishers. This was quite frequently done. One group of respondents argued that publishing arrangements should be on a "non-exclusive" basis as this would authorise others, both inside and out of government, to reproduce official material and thereby broaden the scope for public access. Other respondents argued that the Crown should retain typography rights to published editions to permit reproduction, e.g. by photocopying, without the need for separate permissions arising. The Government commented that this issue raised implications both for government and also private sector re-publishers using Crown copyright protected material for value-added products. Guidance would be issued on this question by HMSO to all departments detailing standard terms on non-exclusive licensing and typographical arrangements which could be "incorporated into all publishing agreements negotiated by Government departments". ${ }^{28}$

The third matter raised by the White Paper concerned "tradeable information" and related "charging policy". The view had long been held by HM Treasury and successive governments that public sector information was a valuable commodity that could and, indeed, should be exploited in the public interest. Such "information assets" would "have potential, not only in supporting the business of government, but also in supporting the economy as a whole”. ${ }^{29}$ This category of raw information was often produced as a by-product of core activities, and would become potentially commercial where value of some kind had been added.

\footnotetext{
${ }^{22}$ Ibid., para 6.1 For example, birth, death and marriage certificates, completed forms and census data which "have not become public records".

${ }^{23}$ This includes the publication of blank security documents which “could be open to fraudulent use, including driving licences and passports.

${ }^{24}$ Ibid., para 5.1 .

${ }^{25}$ Ibid., para 7.3 .

${ }^{26}$ This could include "compilation with other related material”, "provision of accompanying analysis, commentary, annotation, indexing or cross-referencing", or "provision of text-retrieval software". Ibid., para 7.8.

${ }^{27}$ Ibid., para 5.1. The White Paper favoured retention of the value-added pre-condition where it sustained the "financial viability" of official published works or "underpinned commercial arrangements between departments and the private sector which are the result of open competitive tender”. Ibid., para 7.9.

${ }^{28}$ Ibid., para 7.7 .

${ }^{29}$ Ibid., para. 9.1 
The critical issue for the Government in relation to this type of material continued to be the costs to the taxpayer in maintaining the activities from which tradeable information was produced. There needed to be a balance struck between recovery of the costs involved and the benefits to be gained from wider distribution of the material. Ordnance Survey was cited as a good example of cost recovery in its published materials that was "fundamental to the maintenance and development of high quality national mapping”. ${ }^{30}$ The White Paper acknowledged, however, the strong support in the consultation phase for differential charging structures. In reply, the Government pointed to many instances of tradeable information being made available by both public and private sector publishers free of charge to schools, libraries and citizen's advice bureaux. In other cases such material was frequently offered, at cost, for research and private study. The line had to be drawn, though, where commercial exploitation was involved. In such a case the taxpayer had a legitimate interest in sharing in the profits.

With regard to the decision making process in such matters, the Government identified a number of potential models which were currently in use and which it believed complied with competition rules. HMSO would continue its supervisory role, working closely with departments, but the latter would retain the freedom to determine how works, which they originated, should be published. ${ }^{31}$ At issue was the nature and extent of collaboration between the department and the commercial publisher and how this would work in practice. The answer lay in re-asserting the policy of "access" while recognising the legitimate government interest in the trading of public sector information. ${ }^{32}$

The White Paper concluded with a series of "what happens next" statements. At the forefront would be a series of seminars, workshops and guidelines, the latter to be published by HMSO in collaboration with departments, designed to explain the new policy arrangements for Crown copyright. In addition, the ongoing process of reviewing existing departmental delegations of authority from the Controller as Queen's Printer would continue, "to ensure that they give effect to the operational requirements of departments mirroring their changing needs in managing their information". 33

\section{Crown copyright policy - formulating a strategy}

At this stage it is worth reiterating the point made earlier that Government strategy for the future management of Crown copyright had moved and was to be inextricably linked to the "new opportunities" presented for dissemination of official information by digital means. ${ }^{34}$ What was needed was a Crown copyright management "blueprint" which catered, "not only for the needs of business and professional and specialist interest groups, but also for the citizen". In other words, the aim was to provide greater transparency for interested parties in identifying the type of official information available, as well as a management process for the regulation of access and/or commercial exploitation that was flexible, workable and cost effective for all concerned.

What had emerged was a clear understanding that Crown copyright policy was not something that could or should operate outside the mainstream of policies directed at public sector information regulation generally. The issue was to be handled within the broader field of policy that now gave

\footnotetext{
${ }^{30}$ Ibid., para 9.2. The UK Hydrographic Office, producers of navigational charts, was another.

${ }^{31}$ Ibid., para. 9.6.

32 The Government argued that the "value of a commercial market in governmental tradeable information was already acknowledged in the Treasury led "wider markets initiative” - see: Selling Government Services into Wider Markets, Enterprise and Growth Unit, HM Treasury, July 1998.

${ }^{33}$ Ibid., para 12.5 .

${ }^{34}$ See note 14 ante.
} 
higher political priority towards releasing the potential of e-commerce. ${ }^{35}$ It was also to be shaped by the ongoing "cross cutting" review of the "knowledge driven economy" 36 and the commitment to increase the "efficiency of the public sector through the Government’s "wider markets initiative". ${ }^{37}$

\section{1 e-commerce@its.best.uk 1999}

This Report, produced in September 1999 by the Performance and Innovation Unit (PIU) of the Cabinet Office, was commissioned by the Prime Minister in order to define a strategy for making the UK "the best environment in the world for e-commerce". ${ }^{38}$ Priorities included breaking down business inertia towards e-commerce, ensuring that government embraced e-commerce in its own activities and developing closer co-operation between government and industry in any programmes connected with e-commerce development.

The contribution of Crown copyright arose in connection with one aspect of the Government's interactive role with business viz. procurement, service and information delivery. Cutting across that was the "transformation" of internal processes within the public sector in response to the digital revolution. The Report, in seeking to transform information and service delivery, wanted to encourage dialogue so as to find ways by which the private sector might challenge "traditional methods" of service delivery. The team behind the Report welcomed the White Paper's decision to continue departmental delegations of authority regarding the handling of publication of their own generated information, but called for more to be done to remove the bureaucracy involved. ${ }^{39}$ There was still a "lack of a consistent approach across government" which was placing "unnecessary burdens" on publishers wanting to re-sell government data.

One possible answer lay in widening the adoption of a class licensing system. ${ }^{40}$ This would permit licence holders to publish any government information covered by the licence, provided the required conditions were met. The Report called for more analysis of charging structures and administrative arrangements for class licences within the evolving Crown copyright management system.

The Report made clear that it supported the Government's decision not to follow the US approach, whereby all Federal information is freely available to the private sector to re-package and sell it on in any way it chooses. ${ }^{41}$ It was right to develop a scheme that would ensure the integrity of Government information, while enabling the latter to trade in and add value to its own information. Under the class licensing scheme, for example, quality standards could be set as a pre-condition to private sector re-publication. If the integrity of the information product was in question, the licence could be revoked. On the other hand, the class licence could impose obligations on departments to provide background data to government publications in a more consistent way and thereby enhance the quality of the data supply to the user. The Report called for HMSO, supported by the DTI, to establish arrangements with the private sector for a dialogue over these issues to commence by December 2000. ${ }^{42}$

\footnotetext{
${ }^{35}$ e-commerce@its.best.uk, a Performance and Innovation Unit Report, (September 1999).

${ }^{36}$ The Government's Review of the Knowledge Driven Economy was part of the Spending Review 2000 of HM Treasury.

${ }^{37}$ Selling into Wider Markets: A Policy Note for Public Bodies, Enterprise and Growth Unit, HM Treasury (December 2002).

${ }^{38}$ Op cit., note 35 para 1.1.

${ }^{39}$ Ibid., para 11.22.

${ }^{40}$ Ibid., Recommendation 11.6.

${ }^{41}$ Ibid., para 11.21.

${ }^{42}$ Ibid., para 15.1 No. 47.

(C) Dr. Stephen Saxby 2005 


\subsection{The Review of Government Information 2000}

No doubt in the knowledge that this would add fuel to the debate, in December 2000, a review within a review was published when the final report of the Review of Government Information was released. ${ }^{43}$ This was part of the Cross-Cutting Review of the Knowledge Economy which was itself part of the Government Spending Review 2000 prepared by HM Treasury. This dealt with spending plans for 2001-2004. Whereas, in the past, much of the copyright policy analysis on exploitation of official information had been based upon attempts to define a set of principles for going forward, this HM Treasury based review was much more focused on the economics and practicalities of the policies. As with previous official publications, the Review acknowledged the considerable financial importance of the information market and the vital role that "information intermediaries" had to play in the distribution of "products and services based on government information". ${ }^{44}$ Information derived from "the statutory and normal workings of government" formed "the largest single information in the developed economy" but the importance and potential value of such data as "fuel" to business was not always realised by departments and agencies and obstacles existed preventing its widespread use and exploitation. ${ }^{45}$ Among the restrictions identified by the private sector during the review were: "an unnecessarily high administrative burden associated with using government information; .....inconsistent licensing policies; ... a lack of a comprehensive catalogue, or even someone who knows, what information is available for commercial reuse; ...unhelpful, and often junior, officials lacking knowledge leading to blockages or delays in processing requests because they are seen as low priority; ...confusion about the copyright status of public bodies and their information, and where to apply for a licence; .... and prices for re-using government information which are often perceived as too being too high and the fact that for each transaction the price has to be negotiated because there is no clear pricing policy across government."46

The first task set by the review team in seeking to respond to these observations was to define the role of government in the information market. It concluded that the nature of its information activities varied widely between departments and agencies, with overall copyright responsibility for the process resting with the Controller of HMSO. Information was published in a variety of formats, either by departmental in-house staff or by a printer or software house or other private sector agent, who would be paid to prepare or assist in the preparation of the information for publication. In some instances customers could access databases for information. The Review concluded that there was a need for a clearer explanation and definition of its role in the sector to include compliance with new demanding service standards. Three issues needed to be looked at: economics and pricing, licensing and countering departmental inertia.

\section{(i) Economics and pricing}

In looking at the income figures for the publication of Crown copyright information, the Review found ${ }^{47}$ an increase of $£ 141$ million - up to $£ 340$ million - compared with the $£ 199$ million reported in the 1998 Green Paper. ${ }^{48}$ Nearly all the income received (92\%) was accrued by trading funds ${ }^{49}$ with some 53\% generated by sales to non-government customers. Yet there were difficulties

\footnotetext{
${ }^{43}$ Cross Cutting Review of the Knowledge Economy Review of Government Information Final Report (HM Treasury, December 2000)

${ }^{44}$ Ibid., para 1.2. The traditional information market was estimated to be worth about £13 billion in 1997 and electronic information $£ 4.4$ billion.

${ }^{45}$ Ibid., para 1.3

${ }^{46}$ Ibid., para 3.8 .

${ }^{47}$ Ibid., para 4.7.

${ }^{48}$ Op. cit., notes 2 \& 8 ante.

${ }^{49}$ See note 12 ante.
}

(C) Dr. Stephen Saxby 2005 
comparing income streams from trading fund operators with other departments and agencies. Trading funds tended to charge both government departments and non government customers for the supply of material, whereas the income figures of departments did not cost information commissioned for internal consumption, as departments did not normally count this amount in their calculations. The clear interpretation that emerged was that, in relation to exploitation of official information, while trading funds operated within the wider economy, departments had largely confined themselves to serving the information needs of government. As an aside, the review also noted that only $10 \%$ of reported income came from licensing.

The central economic question posed by the Review was whether the way in which government priced its information created a barrier for commercial re-use? Normally the expectation was that, unless agreed otherwise for policy reasons, full costs should be recovered. The alternative was to adopt a policy of marginal cost pricing: in simple terms to charge no more than the production cost of supply. Treasury analysis, however, did not support the marginal cost pricing approach for the licensing of all government information since the dissemination gains were likely to be offset by fiscal burdens elsewhere in the economy, including the taxpayer. On the other hand, the policy might bring social benefits, with demand for information products growing as a result of its innovative repackaging. The review concluded that further empirical work needed to be done on the economics of information pricing before a recommendation could be made.

The review did, however, recommend one decisive step be taken on pricing. There was a difference between information the Government had because it was the Government and incidental information of which government was not the main consumer. Trading fund operators, for example, were quasi-commercial bodies "delivering services which go considerably beyond the scope of government's own needs, while they also provide value added services as well as raw data”. ${ }^{50}$ Trading funds operated in a competitive economy. Moreover, each fund was different from the next. Their prices were not as flexible and a stronger case could be made for service users to contribute beyond the marginal costs to the fixed costs of their businesses. Accordingly, the Review recommended a policy of encouraging price differentiation that would recover fixed costs equally between service users, but on a variable cost basis between services according to the type of service in question. Elsewhere, however, departments and agencies, other than trading funds, should move to "an immediate marginal cost pricing policy" unless dictated otherwise by statute. ${ }^{51}$ Such arrangements should apply to the licensing of raw data, but not where government had already added value to the material. Where value-added services were involved market prices should operate, ensuring a "level playing field" between all market participants. ${ }^{52}$

\section{(ii) Licensing policy}

\footnotetext{
${ }^{50}$ Op. cit., note 43, para 5.18. "Raw data” is defined as "information collected, created or commissioned within Government which is central to Government's core responsibilities. The supply of selected components of a raw data package, exactly as in the package is raw data supply., but the supply with further analysis, summarisation etc., or of data at a different level of aggregation to that used by Government, is not raw data for the purposes of this report but is value added information”. Source: Charges for Information: When and How - Guidance for Government Departments and other Crown Bodies (HM Treasury July 2001) p.14 Key definitions.

${ }^{51}$ Ibid., para. 5.20.

52 Ibid., para 5.23. "Value added information" defined as: "information where value is added to raw data enhancing and facilitating its use and effectiveness for the user, for example through further manipulation, compilation and summarisation into a more convenient form for the end user, editing and/or further analysis and interpretation, or commentary beyond that required for policy formulation by the relevant government department with policy responsibility. It also includes supplying retrieval software, or where work on material is included as part of the compilation of related data, and where there is not necessarily a statutory or operational requirement for Government to produce the material”. Source, op. cit., note 50 ante.
} 
The review indicated that its proposals on pricing would require consideration of the implications for licensing policy. It re-iterated the conclusions of the PIU Report, e-commerce@its.best.uk of September 1999 which called for a wider class licence model and a simplified process. As a result of its recommendations a working programme had been set up by HMSO, in conjunction with its user group, ${ }^{53}$ to produce a simplified licence by the end of 2000 as well as a Fair Trading Charter designed to establish standards enforceable across government. The Review had little hesitation in endorsing the original objectives of the PIU report. Licensing was an integral part of the process that enabled the publication of official information, either jointly between department and private sector publisher, or by selling data in electronic form - frequently in partnership with the private sector. Some products would have value added to them prior to publication by the department, with or without assistance. Others would comprise raw data to be developed by the private sector licensee.

Having endorsed the marginal cost pricing approach the Review did, nevertheless, seek a relaxation of the rule in respect of a data set or information source that had been "particularly expensive to collect or where the Government has gone beyond its own needs - such as in some national statistics”. In these circumstances the recommendation made was to permit fees to be fixed in a range from $£ 1,000$ - $£ 10,000$ and levied by HMSO, so that a contribution could be recovered in respect of such overheads without the risk of delay caused by the need for prior negotiation. In this way the business activities of departments like the Office of National Statistics could be secured, while minimising any delay in commercial re-use. This appeared to be the only response to a point made earlier in the Review that the implications of the partial move to marginal cost pricing, on current levels of publishing income for the Government, needed to be considered. The concern was that potential private sector partners might wither at the prospect of committing themselves to the financial risk of obtaining "First Publication Rights" as "official publisher" if others could come on board later on and compete on marginal cost and standard licence terms. ${ }^{54}$

\section{(iii) Departmental inertia}

The third main area touched on by the Review was how to promote access to unpublished government information since there was little evidence of any pro-active dissemination by its custodians, that task being somewhat marginal to the core activities of most departments and agencies. The Review linked this issue with the wider review underway into electronic service delivery which proposed that all government services for citizens and business should be available online by 2008. ${ }^{55}$ The Review indicated that it wanted both the private sector and voluntary organisations to have access to such content as this would facilitate the delivery of services. The Government needed to do better in providing an interface that could act as a guide to the information resources around Whitehall, promote co-operation between the private sector and departments - ensuring compliance with requests for data access and, in due course, offer a single point of reference for the licensing of most Crown copyright material. ${ }^{56}$

\footnotetext{
53 The Crown copyright User Group was established in 1999 by HMSO to facilitate discussion of the practical effects of implementing new policies following publication of the White Paper, The Future Management of Crown Copyright, Cm4300 (SO March 1999). It was superseded in April 2003 by The Advisory Panel on Crown Copyright.

${ }^{54}$ Op. cit., note 43 ante, para 5.24.

${ }^{55}$ Op. cit. note 15 ante, Chapter 5 para 16.

${ }^{56}$ Ibid., Para 7.4. The somewhat sanguine comment was: "There is little doubt that even the most adroit private sector content providers find Whitehall's information resource a difficult seam to mine”.
} 
To pursue these objectives the Review recommended that HMSO take on this role and become a "regulatory body for government content". ${ }^{57}$ With less work to do on the licensing and income generating front, HMSO would be in a position to assume the role of "honest broker" and re-brand itself in both image and function. A number of tasks were identified for the "new body" including the imposition of minimum standards in the publication of information asset registers; securing publication of class and click (online) licences; ensuring online notification by departments of licensing requests so that performance league tables could be produced; and making sure that, once agreed upon, departments complied with the Fair Trading Charter as well as any other departmental specific service standards that may be in operation. In addition the Review envisaged that HMSO would operate a complaints procedure with power to act where departments failed to comply with their own published service standards. ${ }^{58}$ It called upon the Government to issue a consultation paper as soon as possible to define "the future scope for a new regulatory body elaborating on proposals set out in this report”. ${ }^{59}$

To facilitate these developments the Review also recommended that any existing delegations of authority, other than to trading funds, for the re-use of official information should be rescinded and taken back into HMSO's control. In fact the new regulatory body, when established, should work together with a licensing task force to bring charging policies and licences "into line with those set out in this report”. ${ }^{60}$ A timescale should also be established for online access to departmental information asset registers. It further proposed that a presumption be adopted that public information would, from now on, be available in digital form and a prohibition be introduced on exclusive deals for "digitalisation" of public sector information where this was found to unreasonably restrict access and/or commercial re-use of the material. It also called upon public sector copyright owners, other than the Crown, such as local authorities and non-departmental public bodies, to review their own charging and licensing policies in the light of the HM Treasury review. ${ }^{61}$

\section{Implementing the strategy}

\subsection{The HM Treasury review}

The three year period of policy reflection, starting with the 1998 Green Paper $^{62}$ on Crown copyright and ending with the 2000 Review of Government Information, ${ }^{63}$

was critical to the modernisation process that was necessary to put Crown copyright policy in touch with the wider policy implications for government of 'digitalisation'. One gets a feeling, at this point, that the ingredients were now in place for establishing a new framework, in which the underlying issues were better understood than ever before: in particular that, in bringing forward the e-Government modernisation agenda, this could not take place effectively without a Crown copyright policy capable of ensuring a vibrant market for the effective use and exploitation of "the largest single information resource in a developed economy". ${ }^{64}$

\footnotetext{
${ }^{57}$ Ibid., para 7.5.

${ }^{58}$ Ibid., para 7.7.

${ }^{59}$ Ibid., para 7.8 .

${ }^{60}$ Ibid., para 7.9.

${ }^{61}$ Ibid., para 8.3

${ }^{62}$ Op. cit. note 4 ante.

${ }^{63}$ Op. cit. note 43 ante.

${ }^{64}$ Ibid., para. 1.3.
} 
In September 2000 the Government accepted the recommendations of the Cross-cutting review of the Knowledge Economy ${ }^{65}$ and, in so doing, committed itself to a public consultation on the new role and responsibilities of HMSO as the regulatory body. Accordingly, in October 2001, the Government published its consultation paper entitled: Licensing of Crown Copyright - HMSO Regulatory Framework. ${ }^{66}$ The consultation focused on the main criticisms of existing arrangements identified by the Review viz., the difficulties and administrative barriers facing potential users in locating information, the lack of a single coherent policy within government for the management of its information resource and particularly "how to decide whether and, on what conditions, to allow the re-use of Government information”. ${ }^{67}$ The consultation, therefore, wanted to test public opinion on its proposed solutions to these problems - a repositioned HMSO as the regulatory body to oversee Crown copyright licensing and a revised licensing policy that would encourage the re-use of this resource and prevent Crown bodies from "blocking other organisations from taking Crown copyright material, adding value and marketing a new product”. ${ }^{6}$

In particular, the consultation dealt with four of the recommendations of the Review; first, that an Advisory Panel of public and private sector representatives be appointed to support the Controller of HMSO in her new regulatory capacity overseeing Crown copyright licensing; second that, other than trading funds, licences to re-use core information from government departments be priced at marginal cost; third, that licences for the re-use of value-added information i.e. information not core to departmental responsibilities be charged on a tariff basis under HM Treasury guidance; and finally, that trading funds should improve their dissemination and pricing policies. ${ }^{69}$ The analysis of responses ${ }^{70}$ was published in July 2002 based on eight key points for which views were sought:

- That HMSO would regulate licensing decisions by departments and trading funds but would not offer a formal self-regulation process for this;

Two thirds of respondents agreed that HMSO should not offer formal self-regulation of its licensing decisions. ${ }^{71}$ The Government agreed arguing that Crown copyright decisions could not be removed from Ministerial responsibilities. There was also strong support for extending the regime to other areas of public sector information. ${ }^{72}$ Different visions for the proposed Advisory Panel were presented with the majority wanting it to have stronger powers. The Government rejected this arguing that the responsibility of the Controller of HMSO could and should not be eroded. ${ }^{73}$

- That all Crown copyright material be eligible for licensing (subject to freedom of information considerations).

Among the issues raised were concerns over the discretion allowed under the Freedom of Information Act. The Government believed that problems of this kind could be dealt with as exceptions. ${ }^{74}$ Others pointed out that Crown copyright material that was not information, such as software, broadcast or photographic archive material, might be caught by the proposed rule as well as work in progress, works never intended for publication or works assigned to the Crown, which

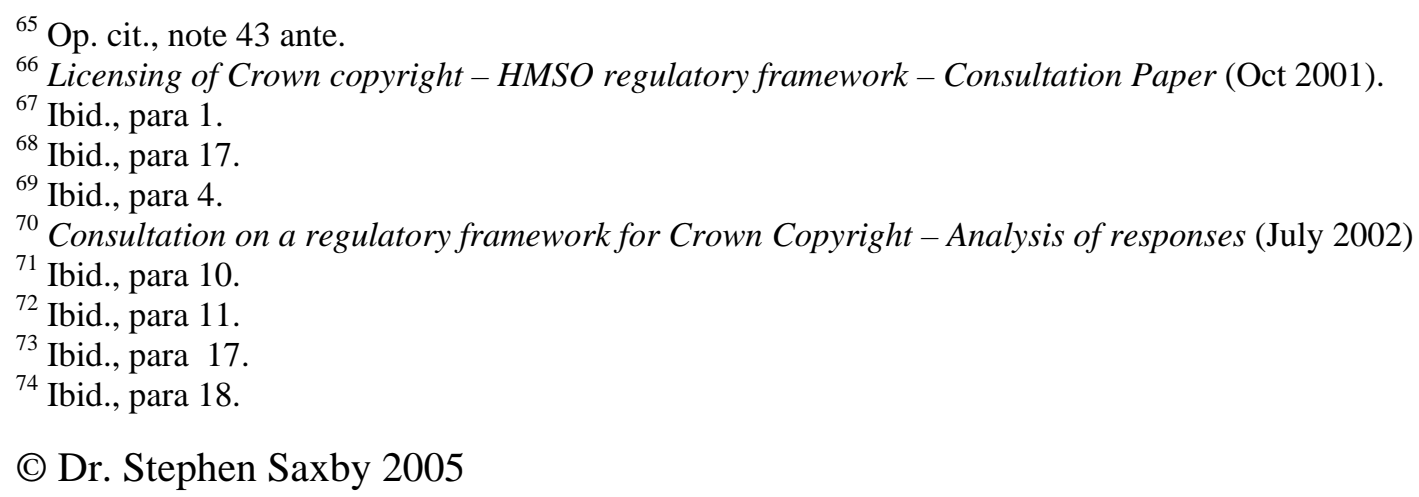


may not have been priced for further re-use. The Government argued that these issues could be addressed by restricting the regime to information and information products and by ensuring that all new assignments contain provision for the material to be licensed on request. ${ }^{75}$

One major concern that went "to the heart of the conflict between the national interest in quality of government information and commercial models for marketing it” were information series, such as Ordnance Survey's 1:25000 and 1:50000 mapping range, which it publishes in full at a level price for each map. Fears were raised that commercial competitors would "cherry pick" the popular areas and market only those. Whereas Ordnance Survey favoured restrictions on the marketing of part series, the private sector wanted no such restrictions. ${ }^{76}$ Surprisingly, the Government offered no view of its own on this point other than to conclude that there was no consensus as to the level of discretion that regulated bodies should have over selecting material not to licence. ${ }^{77}$

- That applications for re-use licences be treated on a similar basis;

This issue drew the largest response in the consultation, the implication of the recommendation being to disallow special pricing arrangements with individual licensees regardless of status. This drew opposition from the voluntary and academic/library sectors which argued for special treatment on educational grounds and problems of cost recovery. ${ }^{78}$ Others argued against since other commodities, e.g. vital utilities were priced without reference to the economic sector of the customer, and lower prices for non-commercial re-use would have to be subsidised, at least in the case of trading funds, by their commercial licensees. In considering these and a number of related arguments, the Government, nevertheless, firmly rejected re-use licences offered at a lower price because the applicant was not working for profit. ${ }^{79}$ Decisions on this had to comply with Competition law and government policy and trading fund price discrimination linked to differentiated products and services should not be overridden by the Controller of HMSO. ${ }^{80}$

- That licences may include restrictions on inappropriate uses;

The main concern here was whether the Government might assume "unnecessary responsibility for monitoring taste and decency". The Government agreed on the need for boundaries and clear objectives in applying this discretion. ${ }^{81}$

- That publication of current prices and pricing policies for licensing Crown copyright material should be mandatory;

This was opposed by all potential regulated bodies but supported by others. The former were concerned that public disclosure of specific prices for products and services would damage information quality. Underlying this was a fear that price transparency would challenge public sector revenues for such products. The Government rejected these fears. If the private sector did compete on price this would either drive down costs to the benefit of users or, if unfair practices were involved, would lead to investigation by the Office of Fair Trading. If competitive pressure

\footnotetext{
${ }^{75}$ Ibid., para 19.

${ }^{76}$ Ibid., para 18.4.

${ }^{77}$ Ibid., para. 22.

${ }^{78}$ Ibid., para 23.

${ }^{79}$ Ibid., para 24.

${ }^{80}$ Ibid., para 26.

${ }^{81}$ Ibid., para 29.
} 
did lead to falling prices, making it difficult for information providers to support data products, there were options that the Government could consider at that stage. ${ }^{82}$

- That HMSO establish a Regulation Division to deal with complaints and giving advice to departments and trading funds on Crown copyright issues;

Once again opinion was divided on this issue between those in agreement with the proposal and those who wanted either stronger or weaker powers for a re-positioned HMSO. The Government rejected these submissions arguing that existing government entities were not comparable to privatised monopolies. Trading funds could be constrained simply by the Government amending its objectives and targets, although it did accept that there was a case for a single body to manage complaints relating to public sector providers including trading funds, where perceptions remained that some unfairly managed their "conflicting duties". ${ }^{83}$ However, the Government continued to put its trust in the rights of complainants to refer matters to "the Office of Fair Trading, the Parliamentary Ombudsman, responsible Government departments, Ministers or any other sources of help". ${ }^{84}$

- That where complaints are upheld HMSO have powers to put matters right;

The consultation paper envisaged that resolution of complaints might lead to the grant of a licence previously refused, a price reduction or revised licence conditions. The Government found broad consensus on these remedies although it recognised that this was dependent, to an extent, on the strength of the regulatory body's powers. ${ }^{85}$

- That HMSO report annually on the cause, handling and outcome of all complaints received.

Enthusiasm for this was "tepid” with suggestions that the Advisory Panel, rather than HMSO, might commission an annual industry report on the regime, thereby providing an element of independent monitoring. Nevertheless the Government concluded that a broad consensus on this recommendation could be found. ${ }^{86}$

\subsection{HMSO’s own consultation}

Published simultaneously with the analysis of responses to the consultation were HMSO's own findings. ${ }^{87}$ These dealt with implementation of three key aspects of the Cross Cutting Review ${ }^{88}$ on departmental pricing, re-use and value added data and regulation of the licensing decisions of trading funds. The Review had proposed ${ }^{89}$ that non value-added departmental data be offered at marginal cost, that value-added data be licensed at market prices and that closer management of trading funds in these matters would offer the most efficient outcome. ${ }^{90}$

HMSO reported that it believed the information industry regarded the following to be crucial to the achievement of the Government's objectives: consistent geographical information on a national

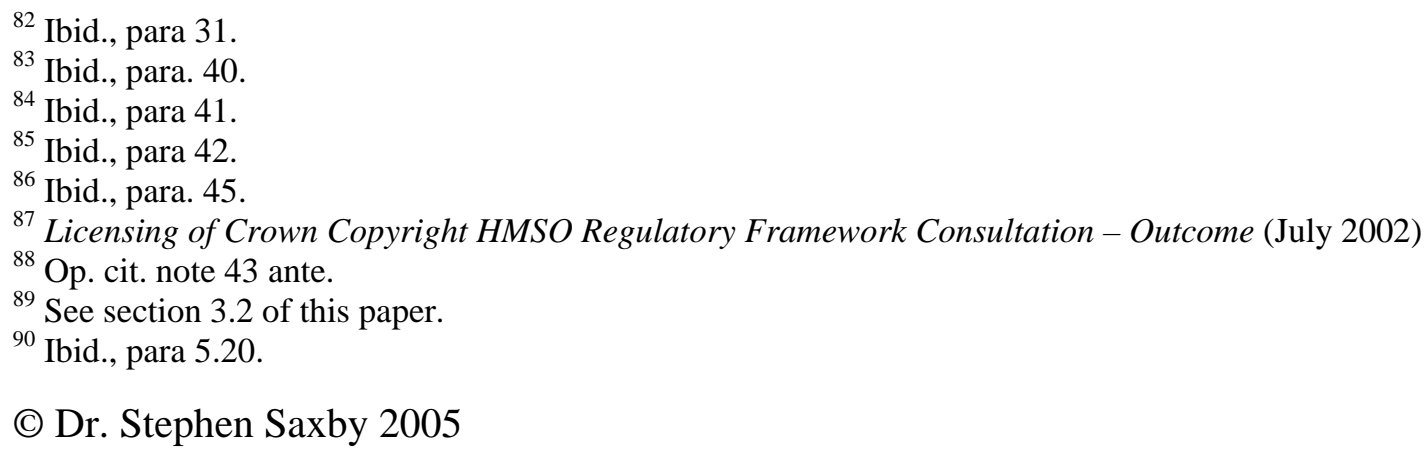


basis; an increased pool of information available for licensing; licenses available for all distribution media; quick decisions without administrative effort for applicants; simplicity, consistency, transparency in licence terms across Government and strict adherence to published licence terms. Public sector bodies, other than the Crown, should also be encouraged to adopt such arrangements. The creation of confidence, clarifying the role of prices charged for licensing, open access to price list and pricing principles and strict adherence to published price lists and principles, were all critical to the success of the plan.

In order to secure the consent of information providers to its dissemination and pricing proposals, HMSO announced that a Fair Trading scheme ${ }^{91}$ would be launched to "codify and project the standards needed to deliver the improvements". ${ }^{92}$ It would apply to all organisations permitted by the Controller of HMSO to licence Crown copyright information for reuse. ${ }^{93}$ A Fair Trader certificate would be offered and Chief Executives of trading funds primarily trading in information would be expected to apply. ${ }^{94}$ This would amount to a statement of commitment, with performance evaluated by audit teams selected, commissioned and financed by HMSO. ${ }^{95}$ If a potential licensee complained about an organisation HMSO proposed a regulatory process which could ultimately lead to the withdrawal of the Fair Trader certificate by the Controller of HMSO. ${ }^{96}$

An important comment came at the end of the Consultation Outcome Statement when discussion turned to licensing. The views expressed could be seen as evidence of the progress made in government towards understanding the concerns of the information industry in seeking to re-use or add value to official information. HMSO declared that discussion with relevant departments and other parties needed to take place to assess the scope for "convergence in access and licensing processes across the public sector to better meet the needs of industry and the knowledge economy". ${ }^{97}$ HMSO commented that the private sector was "not interested in distinctions between Crown and non-Crown copyright or between various financial or policy objectives of different public sector organisations”. ${ }^{98}$

To assist the process it was announced that the Controller of HMSO would establish an advisory group, drawn from all sectors of the information industry, to "advise on how the developing commercial needs and opportunities, constraints and customer aspirations of users relate to the information providers in the public sector". ${ }^{99}$ The group chair would report annually to government on HMSO's “success" in opening up the re-use of public sector information and on developments in the knowledge economy. The annual report would also consider what planning might be necessary to develop the skills mix required to progress these policies within HMSO and provide some analysis of the implications of the types of complaint made under the Fair Trading scheme. Finally,

\footnotetext{
91 The scheme requires "strict adherence to an open and transparent trading regime consistent with the Competition Act 1998”. Signatories must also commit themselves to other principles set out in an Appendix to Annex B of the HMSO Consultation Outcome Statement, op. cit., note 86 ante.

${ }^{92}$ Ibid., para 6.

${ }^{93}$ Ibid., para 7. As of March 2004 there were 26 departments and agencies authorised to license Crown copyright material and 17 that were regulated by HMSO. See: http://www.hmso.gov.uk/copyright/ regulation/about_regulation.htm.

${ }^{94}$ Trading funds that rely on Crown copyright protection for works other than information would not be expected to join. Others, for whom trading in information was not seen as a key role, may instead agree that HMSO's Licensing Division shall manage any licensing applications for their material.

95 Ibid., para 9.

${ }^{96}$ Ibid., paras 15-19.

${ }^{97}$ Ibid., para 21.

${ }^{98}$ Ibid., para 20.

${ }^{99}$ Ibid., para 22. 
the regulatory regime would be reviewed again after two years to assess whether a balance between costs and benefits had been found and to make longer term arrangements. ${ }^{100}$

\subsection{The Wider Markets and e-Government Initiatives}

To complete the chain of recent documentation in the cycle of policy development for Crown copyright to which this article refers, mention should also be made of two HM Treasury Guidance notes dealing with the sale of government services and to a consultation document on supply of egovernment services. Both Treasury Guidance notes, in fact, are consistent with the main lines of analysis already outlined, but deal with tangential issues. The first guidance on charging policy, ${ }^{101}$ published in July 2001, was set in "the context of continued improvements in access to government information" 102 and looked forward to implementation of the Freedom of Information Act 2000 (the FOI Act ${ }^{103}$ within five years. Its main purpose, therefore, was to put Crown copyright policy, set out in the Cost Cutting Review, in the context of the new obligations arising from the FOI Act. In particular, it dealt with the implications of the FOI Act and other legislation, such as competition law, for charging policy, but did not depart from the principles already established.

The second guidance, ${ }^{104}$ published in December 2002, replaced the 1998 Guidance Note ${ }^{105}$ on selling government services to wider markets. The aim of the original Guidance in 1998 was to "provide a framework of policy and good practice for developing commercial activities using public sector assets". ${ }^{106}$ The new Guidance in 2002 updated this statement in the light of the legislation just outlined and added further clarification to policy in the light of the experience already gained in implementing “wider markets” project activity. The Guidance did, of course, apply to a wide range of asset types, both physical and non-physical, including software, databases, expertise, skills, brands and intellectual property and to equipment, land and premises. ${ }^{107}$ While encouraging Government departments and agencies to make "better use of their assets by engaging in commercial services based on them”, ${ }^{108}$ it declared that any such projects involving Crown copyright material should be consistent with Government policy on its management.

The message emanating from the "Wider Markets Initiative", then, was intended to strengthen the drive to encourage the public sector to adopt a more "entrepreneurial approach" to the exploitation of public assets while again, so far as Crown copyright was concerned, working within the newly defined policy structures..

The primary focus of the Consultation on supply of e-government services was to seek views on the involvement of private and voluntary sector intermediaries in their delivery. The Consultation ${ }^{109}$ declared the Government's intent to establish, within three years, a mixed economy in service supply. To facilitate this and, particularly, to help overcome "the business and cultural challenges"

\footnotetext{
100 Ibid., para 24.

${ }^{101}$ Charges for Information: When and How - Guidance for Government Departments and other Crown Bodies (HM Treasury July 2001).

102 Ibid., Foreword.

${ }^{103}$ Freedom of Information Act 2000 (Ch. 36) 30 November 2000.

${ }^{104}$ Op. cit., note 36 ante.

105 Op. cit., note 31 ante.

106 Ibid., Foreword.

107 Ibid., para 6.

108 ibid., Summary.

${ }^{109}$ Policy Framework for a mixed economy in the supply of e-government services - a consultation document (Office of the e-Envoy, May 2003).
} 
to its achievement, a set of framework principles were proposed as a basis for assisting departments in taking their relationship with intermediary applicants forward. One such principle declared that "any charges to intermediaries for the consumption of public sector resources shall be made in accordance with existing Treasury guidelines". ${ }^{110}$ Another established the additional commitment that intermediaries should anticipate "effective and efficient access to public sector informational and human resources to enable successful mediation in the supply of public services". ${ }^{111}$

The response to the Consultation ${ }^{112}$ came in the main from stakeholders with an interest in the development of the mixed economy described. On the charging issue there was a strong need for an effective policy that was consistent, while offering a "level playing field" for all intermediaries. The ethos of "selling" rather than "sharing" public sector data needed to be challenged. Charges for access to, or re-use of, public sector information collected under a statutory duty should not exceed the marginal cost of preparing the material for distribution to the private sector. Moreover, it should apply to all such material, including data held by parts of the public sector not under the remit of HMSO such as delegated departments or trading fund operators. ${ }^{113}$ The policy of charging market prices for value-added information was also questioned.

On the broader issue of co-operation, set out in principle ten, there was, as expected, full support for a policy that aimed to remove barriers to private sector exploitation of official information. The lack of balance in the relationship could not be accepted particularly if this put the quality of service and, therefore, brand reputation at risk. Particular attention needed to be paid to access arrangements for the exchange of information, the complexity of which could often be underestimated. ${ }^{114}$

In December 2003 the e-Envoy's Office published the first set of implementation guidelines ${ }^{115}$ for the achievement of the mixed economy in e-Government service supply. In so doing the Government declared its desire to "address all the issues raised, with the need to maintain momentum" towards achievement of the policy. ${ }^{116}$ On the issue of charging intermediaries for consumption of public sector resources, the Government accepted that there was no intention to charge for time spent by officials in meeting access requests. Nor was it intended to charge for any technical information or organisational data provided that might be necessary in building the business case for a service development proposal. However, in developing an intermediaries' policy on consumption of official information, the Government had no intention of entertaining further discussion about HMSO's policy or Treasury guidelines for licensing and use of Crown copyright material. The Government reiterated that it did not believe its charging arrangements would discourage intermediaries. Charges would only apply "in certain situations with specific government services". ${ }^{117}$ To identify how this might work in all reaches of government it did, however, undertake to help identify where public sector information was being held within those parts of government not within the licensing control of HMSO as such, e.g. local authorities, and to explain how their charging schemes operated.

\footnotetext{
${ }^{110}$ Ibid., p. 27 - Principle No. 7.

111 Ibid., p. 28 - Principle No. 10.

${ }^{112}$ Policy Framework for a Mixed Economy in the Supply of e-Government Services - Official Response to the Public Consultation (Office of the e-Envoy, October 2003).

113 See further: www.hmso.gov.uk/copyright/policy/c_copyright/delegated_depts.htm.

114 Op. cit., note 111 ante, p. 14.

${ }^{115}$ Policy Framework for a Mixed Economy in the Supply of e-Government Services - Implementation Guidelines V. 1 (Office of the e-Envoy, December 2003).

${ }^{116}$ Ibid., p.2 - comment by Douglas Alexander, Minister for the Cabinet Office.

117 Ibid., p. 23.
} 
On the question of access rights in Principle ten, the Government expressed the view that is was fundamental to a successful intermediary relationship with a public sector organisation for there to be "guaranteed access". ${ }^{118}$ It was vital for the intermediary to be convinced of the department's commitment to the project which could be evidenced by the latter's allocation of personnel to develop the initiative and to maintain the relationship thereafter. This might involve providing intermediaries with information on "cost per transaction of service, operational and performance data, management reports, planning information, numbers of employees, locations, technical infrastructure and business processes". ${ }^{119}$ Much of this could be identified and discussed while applying the service development model outlined in the guidelines to the process and in the creation of service level agreements that spelt out what had been agreed.

\section{Assessment}

If the period from 1998 to 2004 might reasonably be characterised as a time of policy reflection and assessment, the time since then has witnessed a number of concrete developments that have gone a long way towards establishing the perceived way forward in the regulation of public sector information in the medium term. There is a sense of the policy analysis coming to fruition spurred on no doubt by the passage and implementation of the EU Directive on public sector information (PSI Directive) ${ }^{120}$ as well as the coming into force of key parts of the Freedom of Information Act $2000{ }^{121}$ These and other developments will now be looked at in turn.

\subsection{The Office of Public Sector Information}

The Office of Public Sector Information (OPSI) commenced work on $16^{\text {th }}$ May 2005 led by its Director, Carol Tullo, formerly of HMSO. It will be responsible for co-ordinating policy standards on the re-use of public sector information and in particular ensuring that the UK implementation of the PSI Directive offers a practical and transparent framework for the removal of obstacles to reuse. OPSI will be attached to the Cabinet Office and has been formed out of HMSO. HMSO, however, retains its status and will continue to operate within OPSI pursuing its "core activities of the management of Crown copyright and database rights, publication of legislation and provision of official publishing guidance”. ${ }^{122}$

Within OPSI five teams have been established to pursue these objectives. The information policy team will manage the process of licensing Crown and Parliamentary copyright material, defining policy and offering advice and guidance. The Standards Team is charged with developing OPSI's role that grew from the analysis in the Cost Cutting Review of the Knowledge Economy ${ }^{123}$ in 2000. This includes taking forward the Information Fair Trader Scheme and embedding the role of the Advisory Panel on Public Sector Information. ${ }^{124}$ Thirdly, there is the e-Services team working to implement an overall business strategy for e-service delivery. Fourthly, the publishing services team will oversee the publication of all UK legislation and the editorial responsibilities that go with it, including production of the Official Gazettes, Command Papers and the Civil Service Yearbook. It will also advise government departments on a range of official publishing issues. Finally, the

\footnotetext{
118 Ibid., p. 25.

119 Ibid.

${ }^{120}$ European Directive 2003/98/EC on the re-use of public sector information

${ }^{121}$ Freedom of Information Act 2000 Ch.

122 Office of Public Sector Information Team information at: www.opsi.gov.uk

${ }^{123}$ See further sections 3.2 and 4.1 ante. See footnotes 43 and 63.

124 See post.

(C) Dr. Stephen Saxby 2005
} 
Business Support team will oversee the financial management of OPSI and offer a range of services dealing with quality, complaints, personnel and IT issues.

There is no doubt that the separation of HMSO functions from the broader remit of managing and co-ordinating policy standards for the re-use of public sector information was a necessary and important step in responding to the message coming out of the earlier policy analysis. It was also an essential step once the EU had legislated and the Freedom of Information Act was implemented. The remit of HMSO in the management of Crown copyright had become only one part of the equation and this has now been recognised.

\subsection{The Information Fair Trader Scheme}

The Cost Cutting Review of the Knowledge Economy in 2000 recommended that all government trading funds should commit themselves to improving their information, pricing and dissemination schemes for public sector information. ${ }^{125}$ Standards would be promoted through an 'Information Fair Trader Scheme' to be implemented by HMSO. Now the scheme is established the first set of review data is becoming available. The primary aim of the scheme is to ensure that "re-users of Government information, whether in the voluntary, professional or commercial sectors, can be confident that they will be treated reasonably, consistently and fairly by public sector information providers". ${ }^{126}$ It requires participants to publicly commit to the scheme, undergo a verification process to ensure that commitments can be met and establish a complaints process that can ultimately be investigated by HMSO if all internal processes have been tried first and have failed to resolve the matter. ${ }^{127}$ Chief Executives or their equivalent must also personally commit to the five principles for the re-use of Government information: “openness, transparency, fairness, compliance and challenge”. ${ }^{128}$ Of greatest significance, perhaps, is the fact that the "openness" principle produces an expectation that all information created by a trading fund will be available for "legitimate re-use" by a customer under licence. Where this is not the case with specific data sets Chief Executives are expected to give reasons for such restrictions. ${ }^{129}$

As at March 200513 trading funds were accredited under the scheme including HMSO itself, Ordnance Survey, the Met Office and HM Land Registry. ${ }^{130}$ Ultimately all Crown bodies that hold licensing delegations from HMSO must join but this has been expanded in 2005 to include volunteer members from the wider public sector under the "best practice model" promoted by the Re-use of Public Sector Regulations ${ }^{131}$ which implement the EC Directive on the re-use of public sector information. ${ }^{132}$

\footnotetext{
125 See note 91 ante et seq.

${ }^{126}$ Review of the first four IFTS Verifications, HMSO 4 September 2003 para 2.

${ }^{127}$ Information Fair Trader Scheme, Cabinet Office HMSO 2005 section 2

${ }^{128}$ Ibid., section 3.

${ }^{129}$ This could mean limiting the material licensed, prohibiting uses of the material or limiting the customer base.

${ }^{130}$ Others are UK Hydrographic Office, Driving Standards Agency, Registers of Scotland, Environment Agency, Ordnance Survey NI, British Geological Survey, COI Communications, Medicines and Healthcare Regulatory Authority and the Fire Service College. Source: Information Fair Trader Scheme Review - The First Two Years, Cabinet Office HMSO January 2005, pp. 4-5.

131 S.I. 2005 No. 1515 The Re-use of Public Sector Information Regulations 2005.

${ }^{132}$ Directive 2003/98/EC of the European Parliament and of the Council of 17 November 2003 on the re-use of public sector information.
} 
Fulfilling a commitment made in the Outcome of the Licensing of Crown Copyright HMSO Regulatory Framework Consultation ${ }^{133}$ the Government published its review of the Fair Trader Scheme in January 2005. ${ }^{134}$ Its aim was to consider the benefits that the scheme had brought for both re-users of public sector information and the public sector organisations themselves. The Review found that while the scheme had been successful in "encouraging members to be more open with their information, to treat all customers fairly and to be transparent about licensing policies and procedures.... what was lacking was transparent guidance about what information is actually available for re-use". ${ }^{135}$ In response the Review suggests that the scheme has improved the information flow of guidance via members' websites and leaflets. It has also raised awareness as to the value of the information held and increased appreciation of the fact that, although much of the information held may not look particularly interesting or usable, "someone somewhere may have an idea of how it can be re-used". ${ }^{36}$

On other issues the Review also found that some pricing problems still existed. The practice of free exchange of information between different public sector bodies needed to end as this was unfair to the private sector. On the other hand HMSO, through its participation in the scheme, had built up a wealth of experience and understanding of the trading activities of members and so could share best practice and encourage consistency of approach in the licensing of re-use of public sector information. The Review seeks to dispel other criticisms that the scheme lacks credibility, is marginalized and that not all recommendations are implemented. It points out that not all candidate organisations are accredited since three had failed their initial verification process. The expectation was always that candidates would need to fulfil all key criteria, but not necessarily every single requirement of the scheme. Any such problems can be put right within an agreed timescale and, if not met, then accreditation may be withdrawn. On the accusation that the scheme was not being embraced HMSO dismisses this and points to its efforts to raise the profile of the scheme and to the fact that the Re-use of Public Sector Information Regulations 2005 will ensure that the scheme develops and expands as a model of good practice. Finally, on the issue of non compliance the Review points out that, once accreditation is complete, an action plan for implementation of the recommendations must be prepared. HMSO also has a programme of re-visiting members to check on progress within a six to nine months time band.

The Review concludes by considering what the future holds. It notes that, since 2002, the emphasis has shifted from the focus on licensing of Crown copyright material within government trading funds to the broader licensing of Crown and non Crown copyright information throughout the wider public sector. The overall aim remained accurate which is to "ensure that re-users of public sector information, whether in the voluntary, professional or commercial sectors, can be confident that they will be treated reasonably, consistently and fairly by public sector information providers.”"137 IFTS was not a "one size fits all” policy but should be used flexibly to meet the differing information responsibilities of a range of public sector bodies. Similarly, the process by which a candidate organisation joins the scheme should be flexible. Where full verification is required for departments holding significant quantities of public sector information, the full rigours of that should operate. However, for organisations with significantly less volumes of potentially publishable material, a self assessment arrangement based on a desk audit model might be more

\footnotetext{
${ }^{133}$ Op. Cit. note 87 ante, para. 24: "The Government will review the regulatory regime to check on its effectiveness, to ensure that the balance between costs and benefits is appropriate, and to determine longer-term arrangements, after two years”.

${ }^{134}$ Information Fair Trader Scheme Review - The First Two Years, Cabinet Office HMSO January 2005.

135 Ibid., p.8.

136 Ibid.

${ }^{137}$ Ibid., p. 10.
}

(C) Dr. Stephen Saxby 2005 
appropriate. Which might be the more appropriate model to go for would be a joint decision between the OPSI Standards Team and the public sector body concerned. ${ }^{138}$

\subsection{Information Asset Register}

An important component of the Information Fair Trader Scheme is the desire on the part of government to improve mechanisms for accessing public sector information. In order to achieve this it is important for departments to know what information assets they have. The White Paper, Future Management of Crown Copyright ${ }^{139}$ suggested that HMSO should "provide a gateway and central information point to guide and direct a route through the maze of official government information and materials.” ${ }^{140}$ The Information Asset Register (IAR), launched in March 1999, is the Government's chosen vehicle for achieving this objective. OPSI now leads responsibility for development and co-ordination of the IAR via OPSI's Inforoute website. ${ }^{141}$ The IAR is defined as a consolidated list of the Government's information assets with each record describing an individual asset in terms of its content and location. ${ }^{142}$ Search criteria include by organisation, subject, title and geographical location. The IAR is similar to schemes run, for example, by the US and Canadian governments - the US Government Information Locator Service and the Canadian Info Source database. $^{143}$

The original target for the development of the IAR was that, by the end of 2001, all Crown bodies should have created an IAR in their departments. ${ }^{144}$ In fact this target was not met there being 22 departmental IAR's in place by the end of 2000 and 56 by the year end 2001 . As at $18^{\text {th }}$ February 2003 only 60 out of 288 departments or public sector organisations appeared to have any IAR records in place and in 25 of these cases the number of records recorded were less than $10 .{ }^{145}$ As at $31^{\text {st }}$ January 2004, 83 organisations had an IAR in place with approximately 2600 searchable IAR records online. ${ }^{146}$

If these figures are accurate there can be no doubt that progress towards establishing a comprehensive IAR database has been slow. The relevant section of the OPSI website dealing with the IAR is remarkably lacking precise information as to the percentage of departments and organisations currently operating an IAR and the number of records now online. However, since April 2002 the former HMSO e-Services team, now operating within OPSI, has been looking at ways to streamline and organise a "joined-up" approach to managing the IAR. The product of this research activity is the IAR Redevelopment Project which is looking for a "cohesive plan" for the future development of the IAR. Departments have been questioned about issues related to the creation and provision of information for the IAR and end users on customer issues about use of the IAR. ${ }^{147}$ In the light of this the Government continues to argue that the IAR is a key part of its

\footnotetext{
138 See ante section 5.1 and note 123 .

139 Op. cit. note 14 ante.

140 Ibid., para. 8.3.

${ }^{141}$ www.opsi.gov.uk/oar/index.htm. Users need not know which department is responsible for a particular topic as, by using the inforoute search engine, they will be able to identify which department holds information on a specified subject. There will also be some explanation about that information, the format in which it is held and contact details within the department.

${ }^{142}$ Her Majesty's Stationery Office Publication Scheme (HMSO December 2004) p.5.

${ }^{143}$ At www.gils.net/ and www.infosource.gc.ca/index_e.asp respectively.

${ }^{144}$ Information Assert Register Report 2001p.1.

${ }^{145}$ IAR Departmental Progress and Current Status as at 18 February 2003.

${ }^{146}$ Her Majesty's Stationery Office IAR Redevelopment Project History and Evolution HMSO January 2004 p. 3.

${ }^{147}$ See Her Majesty's Stationery Office IAR Redevelopment project Research Stage 1 Departmental Questionnaire, January 2004 and Her Majesty’s Stationery Office IAR Redevelopment project Research Stage 2 Inforoute Usability Study, January 2004
} 
agenda for "freeing up access to official information". ${ }^{148}$ It also now sees the IAR redevelopment via the Inforoute webpage as part of the broader e-government agenda, supporting such initiatives as data sharing across information providers to "feed the knowledge economy". ${ }^{149}$ It will also meet obligations set out in the Freedom of Information Act and EU Directive on re-use of official information. ${ }^{150}$

As part of its e-government agenda the Government is also looking more closely now at its whole information management strategy. Accessing public sector information is perceived to be a key part of that, so there is now more focus on modernising the configuration of the IAR that will be more "interoperable and compatible with existing government systems" so as to allow a more open exchange of information. ${ }^{151}$ The technical methods employed by departments to operate their document management arrangements must be compatible with inforoute technology to get the best out of the IAR. There does, however, seem to be a lot of work required before the full benefit of the IAR can be perceived. Work continues to improve processing arrangements and automate key processes so as to reduce the time span between creation of information and its availability online. OPSI will be monitoring usage of the IAR and provide departments with feedback on frequently accessed and popular sources of information. It is also developing a "next generation IAR" with advanced search capability to help public sector bodies identify their information assets more easily. At the same time the key message appears to be the need to link existing and emerging information initiatives and policies together "to ensure that public sector information assets are easy to manage and easy to find, use and share." 152

\subsection{Advisory Panel on Public Sector Information}

A further development that has become established within the policy development process is the formation of a non-departmental public body - the Advisory Panel on Public Sector Information (APPSI) - established to advise Ministers strategically on how to "open up opportunities for greater re-use of government information by private and voluntary sectors of the economy ... and about changes and opportunities in the information industry". ${ }^{153}$ APPSI was established on $14^{\text {th }}$ April 2003 but was originally named the Advisory Panel on Crown Copyright. This was changed in 2004 to reflect the fact that policy on Crown copyright was now only one aspect of the many issues surrounding re-use of public sector information and that public sector information itself was now at the centre of much policy formation. It was important for the title of the Advisory Panel to reflect this.

The first Annual Report ${ }^{154}$ of APPSI was published in July 2004 and offers a useful insight into the work of the Panel and the likely future contribution it will make. The Report had four key messages for government. The first was that awareness of the importance of the re-use of public sector information was low. ${ }^{155}$ Public interest needed to be stimulated beyond engagement with the new

\footnotetext{
148 Ibid., p. 4.

149 Ibid., p. 4.

150 See post.

151 Op. cit., note 146 p.6.

${ }^{152}$ The Re-use of Public Sector Information: A Guide to the Regulations and Best Practice (Office of Public Sector Information, June 2005 para.6.8.

${ }^{153}$ Advisory Panel on Public Sector Information releases first annual report, Cabinet Office Press Release CAB039/04, 27 July 2004.

${ }^{154}$ Advisory Panel on Public Sector Information $1^{\text {st }}$ Annual Report 2004 (APPSI July 2004).

${ }^{155}$ For example the Report questions how widely it is appreciated that as far back as 1996 between 12-20\% of the UK's goods and services economy (between $£ 79$ and $£ 136$ billion) was underpinned by geographical information provided by Ordnance Survey.
} 
Freedom of Information regime into re-use of public sector information. The language of public sector information that talked about "re-use of PSI", "core data" and "value-added data" needed to be simplified and clarified.

Second, the Report complained that Government policy was too fragmented in that the policies on re-use pursued by individual departments did not always align with one another. For example, whereas the Cabinet Office promoted re-use of public sector information to "enhance the knowledge economy and the quality and range of government services”, HM Treasury was keen on "leveraging public sector information to generate revenues or reduce the costs of government". Moreover, whereas the Department of Constitutional Affairs (DCA) wanted "more transparent government through freedom of information legislation" the DTI was keen to "enhance the competitive positioning of the UK information industry". ${ }^{156}$ The Report comments that, whereas these individual aspirations are coherent in themselves, taken together they were likely to conflict and would certainly not represent a consistent set of policies on public sector information upon which the public could relate. There was also confusion about the ambit of Crown copyright which applied only to Crown bodies. This meant that different rules on re-use of public sector information might operate among bodies thought by the public to be Crown bodies when, for technical legal reasons, they were not. Local government was also beyond the remit of Crown copyright, as were the different rules applicable to Parliamentary copyright applicable to the Houses of Parliament.

On this issue the Report recommended that the Government should move towards a more coherent set of policies for public sector information without delay. A joint working party with representatives from DTI, DCA and HMSO should be established to identify overlaps and conflicts and develop co-operation. Beyond that, senior officials should formulate a "single, cost efficient, coherent long-term policy and strategy for information management with the UK public sector". ${ }^{157}$ This should incorporate, not only freedom of information and public sector information issues, but also electronic records management, e-government agendas, knowledge management within government, data protection, environmental information, national statistics and "importantly" the re-development of the Government’s Information Asset Register.

The third key finding of the Panel was that it was having difficulty evaluating the Government's current approach to commercial exploitation of public sector information since, to its surprise, there was little "robust financial data about the actual or potential value of public sector information available, or about the revenues and profits that it yields across the public sector." 158 It found that data from individual departments was accessible but this was insufficient to give the full picture of what was happening across the entire sector. It also reported that there was still a paucity of economic modelling theory capable of analysing public sector information. Until this was resolved reliance upon "dogmatic thinking” that strongly asserted a particular course of action should be questioned.

Still within this point the Panel also commented that further analysis was needed of the licensing of public sector information by trading funds and the extent to which they competed with the private sector. Some trading funds operated in a similar fashion to businesses in the private sector, gaining significant revenues from the sale of public sector information that was fed back into the running of the trading fund activities. Whilst the Panel's preliminary view was that this general approach was alright, serious analysis would be required to confirm it. The Panel recommended that the Government should recognise that it needed to be more "systematic and rigorous" in its

\footnotetext{
${ }^{156}$ Op. cit. note 154 ante, p.5.

${ }^{157}$ Op.cit. note 154 ante, p.6.

${ }^{158}$ Ibid.

(C) Dr. Stephen Saxby 2005
} 
measurement of public sector information activity. In due course this needed to embrace not just the re-use of public sector information but the outcome of the fuller exploitation of public sector knowledge systems such as the information asset register. ${ }^{159}$

The fourth key finding of the Panel was that HMSO was continuing to perform well in "formulating, implementing and regulating government policy on the re-use of public sector information". ${ }^{160}$ It noted that its website $w w w . h m s o . g o v . u k$ (now www.opsi.gov.uk) received more than 20 million hits per month and remained the most visited government site in the UK. The Panel also declared its satisfaction with HMSO's "click-use" licence scheme for gaining approval for reuse of Crown copyright material. However, it found that the Information Asset Register, while "promising” as a listing of information resources, remained "under-exploited". The Panel recommended that, in whatever reforms of HMSO might be in the pipeline, that it should continue to operate as the body responsible for implementing and regulating public sector information in the UK. ${ }^{161}$

There is no doubt that an independent body of experts with both broad experience of the issues is what is needed in order to provide an accurate critique of the strengths and weaknesses of present policy. What APPSI has shown is that, while movement in the right direction has taken place in broadening the focus on Crown copyright regulation into the nature of access policy to public sector information, there are still many threads of departmental action still in existence that would appear to either inhibit or conflict with the pursuit of that agenda. By standing back and providing impartial and informed feedback, any inconsistencies in the application of the policy can be identified and acted upon.

\subsection{Recent legislation on public sector information}

The assessment of the Government's stance on policy towards public sector information cannot put to one side the impact of recent legislation, both from the European Union (EU) and Westminster, dealing with access policy. From the EU has come the European Directive on the Re-use of Public Sector Information. (PSI Directive) ${ }^{162}$ The rationale for the measure was set out clearly in the Recitals. There were "considerable differences in the rules and practices in the Member States relating to the exploitation of public sector information resources, which constitute barriers to bringing out the full economic potential of this key document resource." ${ }^{163}$ Harmonisation of a minimum set of rules and principles was necessary to ensure that Member States did not legislate in conflicting ways that would hinder the smooth functioning of the internal market and the "proper development of the information society in the Community". ${ }^{164}$ It also did not go un-noticed, of course, that the existing disarray on this issue in Europe had placed the European information industry ${ }^{165}$ at a disadvantage compared to their US competitors which had, for some time, enjoyed

\footnotetext{
${ }^{159}$ Ibid., p. 7.

160 Ibid.

${ }^{161}$ Subsequently, in May 2005 HMSO was subsumed into the Office of Public Sector Information. See section 5.1 ante. It retained some powers relating to the management of Crown copyright but overall responsibility for policy in the reuse of public sector information transferred to the new organisation.

162 Op. cit., note 132 ante.

163 Ibid., Recital 6.

164 Ibid.

165 The European Commission estimates the size of the Information Industry across Europe to be 496 billion euros, employing 4 million people. This compares with a turnover of $£ 18.37$ billion in the UK in 2000. See Explanatory Memorandum to the Re-Use of Public Sector Information Regulations 2005, p.14 para 10.
} 
much more liberal policies on public sector information access and re-use in their own jurisdictions. ${ }^{166}$

The UK has had little difficulty in assimilating the PSI Directive into domestic law. With the aim being to establish a "single, consistent regime governing re-use of public sector information" ${ }^{167}$ the main obligations imposed by the directive were already policy issues for the government. These included processes for encouraging re-use, ensuring transparency and fairness and creating asset lists. Elements of good practice were, therefore, already in place and being kept under review by APPSI. Implementation of the Directive has been by Regulations ${ }^{168}$ that took effect on 1 July 2005. This is supported by OPSI with its guide to the regulations and best practice ${ }^{169}$ that sets out the obligations on public sector bodies, explains to stakeholders in the private sector how the Regulations will work and how complaints procedures, defined by the Directive, will operate.

The second measure is the Freedom of Information Act 2000 (FOIA) ${ }^{170}$ which entered into force on 1 January 2005. In contrast to the PSI Directive, which is concerned with establishing rules for re-use of public sector information, the FOIA grants a general right of access to information held by public authorities. ${ }^{171}$ In order to facilitate access the FOIA requires that departments produce Publication Schemes giving details of the classes of information the department publishes, how that information is published and whether access to it is free of charge or not. ${ }^{172}$ Complementary to Publication Schemes is the Information Asset Register. Departments are required to provide both. In cases where the Publication Scheme fails to provide a satisfactory answer to a FOIA request it is anticipated that the IAR may provide the further guidance to help manage the demand for information. ${ }^{173}$

Although a strong group of exemptions to the public right of access to official information exist, as set out in Part II of the FOIA, the link with the PSI Directive is in the relation between "access" and "re-use" rights that are granted by these measures. However, whereas the FOIA imposes an obligation on public authorities to respond to information requests, ${ }^{174}$ the PSI Directive ${ }^{175}$ and the UK Regulations ${ }^{176}$ which implement it provide that departments may or may not accede to a request for re-use. According to the Advisory Panel on Crown Copyright (APCC now APPSI) the distinction between "access" and "re-use", which UK officials are keen to maintain, is far from clear: "In practical terms, huge bodies of the same public sector information are subject to both regimes, although the obligations imposed and entitlements conferred are by no means the same. And, although they are not co-extensive, both instruments do apply, broadly, to UK public sector bodies." 177

\footnotetext{
${ }^{166}$ Op cit., note 153 ante para 2.3.

${ }^{167}$ Response to the Partial Regulatory Impact Assessment on the EU Directive on the re-use of Public Sector Information, Advisory Panel on Crown Copyright (undated).

${ }^{168}$ Op.cit., note 131 ante.

169 Op cit., note 153 ante.

${ }^{170}$ Freedom of Information Act 2000, Ch. 36. In Scotland there is the Freedom of Information (Scotland) Act 2002, asp 13.

${ }^{171}$ Ibid., s. 1.

${ }^{172}$ Ibid., s. 19.

${ }^{173}$ See: Guidance Note - Information Asset Register and Freedom of Information - a co-ordinated response to information access, Office of Public Sector Information Guidance Note No. 18, $12^{\text {th }}$ April 2002, revised $9^{\text {th }}$ may 2004.

${ }^{174}$ Op. cit., note 171 ante.

${ }^{175}$ Op. cit. note 132 ante, Art. 5(3)

176 Op. cit., note 131ante, Regs. 7-9.

${ }^{177}$ Aligning the FOI and PSI Initiatives in the UK (Version $2.012^{\text {th }}$ February 2004) Advisory Panel on Crown Copyright (as it then was).
} 
APCC noted that with FOIA the responsibility of the Department for Constitutional Affairs and implementation of the PSI Directive in the hands of OPSI, public bodies would need to change their culture if these legislative measures were to be effective in delivery. It pointed out that, whereas in the past the presumption was that public sector information was for official use only, the two regimes of freedom of information and PSI regulation had combined to reverse the position. New rights of access and re-use imposed by these two measures would require a change in attitude among public bodies. APCC concluded by calling for a "single, cost efficient, coherent long-term policy and strategy for information management within the UK public sector. This would embrace not only FOI and PSI but also electronic records management, data protection, environmental information regulations, ${ }^{178}$ national statistics and IAR”. ${ }^{179}$ It also includes ongoing consideration of how to align FOI and PSI and the merits of bringing information management under the umbrella of a single department.

\section{Conclusion}

So how can one sum up the last seven years of policy development in Crown copyright policy? What is clear is that there has been considerable movement and development in a policy that was originally locked into the ongoing desire of government to control public access to official information. Whilst some modest relaxations did creep in at an early stage in relation both to the means of access and re-use, the basic inconsistencies, difficulties and frustrations reported by the private sector continued. Clearly, however, the Government was ready for a debate and that took place in the broader context of emerging e-Government and the desire on its part to engage with the online world and use technology to deliver government services more effectively. Out went the Office of the e-Envoy and in came the e-Government Unit with the remit of developing information policy, setting standards, delivering access and encouraging re-use of public sector information. At the same time the Advisory Council on Crown Copyright broadened its remit within the re-titled Advisory Panel on Public Sector Information. Its work and that of its predecessor has gone a long way to uncovering inconsistencies, flaws and policy weaknesses in what the Government was proposing and is to be warmly welcomed as a mechanism for evaluating policy change and development.

The challenge now will be to see how quickly the ideas and initiatives put in place can be harnessed to good effect. The information fair trader scheme, the information asset register and the response to freedom of information and public sector information regulation are all offering new challenges and new experiences to public servants whose past approach has been very much in the vein that "we own and control public sector information". That must now change. The key test will be the level of usage and re-use of this massive information resource. Will the private sector be in a position to open up new seams of previously undiscovered information that will enable this industry to flourish and thereby feed new information products and services into the general economy? Will UK Plc benefit from the new information streams in the manner that the Government seeks and hopes for? Will the licensing scheme, reformed and streamlined as it is, be a continuing obstacle to the exploitation of public sector information or a workable tool for the re-users to negotiate with government? These are questions that only time can answer. What is clear though is that matters really have moved forward these past seven years. Departments and trading funds most definitely have a clearer picture of what they need to do with their public sector assets. There is a better

\footnotetext{
${ }^{178}$ Separate legislation exists governing environmental information. See: S.I. 2004 No. 3391 The Environmental Information Regulations 2004and Directive 2003/4/EC of the European Parliament and the Council of $28^{\text {th }}$ January 2003 on public access to environmental information, repealing Council Directive 90/313/EEC (OJ L 41, 14.2.2003, p.26).

${ }^{179}$ Op. cit., note 177 ante, Para. 19.
}

(C) Dr. Stephen Saxby 2005 
understanding too as to what is held and what its potential might be but technical issues of information delivery and document management still need to be tackled. Overall, then, the jury is out and will remain out for some time as opinion begins to sift the evidence of what has been accomplished and looks forward to what lies just ahead.

\section{Dr. Stephen Saxby}

\section{July 2005}

\section{5 words}

15803 with footnotes 